\title{
Whole body protein turnover in childhood Crohn's disease
}

\author{
A G Thomas, V Miller, F Taylor, P Maycock, C M Scrimgeour, M J Rennie
}

\begin{abstract}
In order to investigate the effects of treatment on protein metabolism in childhood Crohn's disease whole body protein turnover was measured using a primed constant intravenous infusion of $\mathrm{L}-\left[1-{ }^{13} \mathrm{C}\right]$ leucine and mass spectrometry in 10 children with active disease. Mean rates of protein synthesis and breakdown markedly decreased after treatment with steroids (four) or an elemental diet (six). This suggests that protein synthesis and breakdown are increased during active Crohn's disease in children and are reduced after induction of remission regardless of the type of treatment.
\end{abstract}

There are conflicting views on protein metabolism in chronic inflammatory bowel disease. Using a stable isotope amino acid tracer, L- $\left[1-{ }^{13} \mathrm{C}\right]$ leucine, Motil et al showed similar rates of whole body protein turnover - that is, synthesis and breakdown - in six adolescents with active Crohn's disease and five healthy controls. Chronic inflammation and steroid therapy, surprisingly, had no apparent effect on protein turnover. Powell-Tuck and colleagues, ${ }^{2}$ however, showed that protein turnover increased with disease activity in 19 adults with inflammatory bowel disease. The aims of this study were therefore: (i) To determine whether whole body protein turnover is related to disease activity in childhood Crohn's disease. (ii) To determine possible effects of treatment with steroids and an elemental diet on whole body protein turnover.

\section{Methods}

\section{PATIENTS}

Ten children with active Crohn's disease were studied, all had normal growth. Their ages, site and duration of disease activity are indicated in Table I. The diagnosis was confirmed by clinical, radiological, and histological features. Disease activity was indicated by: increased stool frequency, abdominal pain, weight loss, raised serum orosomucoid, raised erythrocyte sedimentation rate, reduced serum albumin. Activity was graded according to the Lloyd-Still activity index. ${ }^{3}$ Dietary intake was assessed by five day weighed surveys. On diagnosis of relapse the patients were randomly allocated to one of two treatment groups: group A (four patients) received prednisolone $(2 \mathrm{mg} / \mathrm{kg} /$ day, maximum $60 \mathrm{mg} /$ day $)$ and sulphasalazine $(25 \mathrm{mg} / \mathrm{kg} /$ day $)$, they continued to eat a normal diet. The dosage of prednisolone was reduced after two weeks according to clinical response; group B (six patients) received an elemental diet orally
(Elemental 028; amino acids $12 \%$, carbohydrate $77 \cdot 8 \%$, fat $6.64 \%$, energy $399 \mathrm{kcal} / 100 \mathrm{~g}$ before reconstitution with water) (Scientific Hospital Supplies, Liverpool). Energy intake was adjusted to the recommended daily allowance. ${ }^{+}$ No other food or drink was allowed for four to six weeks then normal foods were gradually reintroduced depending on clinical response.

All patients were studied before and after four weeks treatment, when back in remission.

\section{EXPERIMENTAL DESIGN}

Whole body protein turnover was determined by the leucine kinetic model. ${ }^{5}$ After an overnight fast, infusion and venous blood sampling lines were set up in contralateral forearm veins before commencing the infusion. At time 0 , priming doses of $\mathrm{L}-\left[1-{ }^{13} \mathrm{C}\right]$ leucine $(0.66 \mathrm{mg} / \mathrm{kg})$ and $\mathrm{NaH}^{13} \mathrm{CO}_{3}(0.08 \mathrm{mg} / \mathrm{kg})$ were given, then a constant infusion of $\mathrm{L}-\left[1-{ }^{13} \mathrm{C}\right]$ leucine $(0.5 \mathrm{mg} /$ $\mathrm{kg} / \mathrm{h}$ ) was started and continued for 150 minutes. Total $\mathrm{CO}_{2}$ production rate was measured (Beckmann metabolic chart) before the infusion, after 90 and 150 minutes. Expired breath samples for ${ }^{13} \mathrm{CO}_{2}$ were collected into vacutainers (ref 606433, Becton Dickinson, Rutherford, New Jersey, USA) before the infusion and each 15 minutes after it was calculated that plasma leucine would have reached plateau levels.

Venous blood samples were collected at the same times as breath samples and the plasma immediately separated and frozen. $\mathrm{L}-\left[1-{ }^{13} \mathrm{C}\right]$ ketoisocaproic acid enrichment was determined as described previously. ${ }^{6}$ Whole body leucine flux was calculated from the rate of administration of $\mathrm{L}-\left[1-{ }^{13} \mathrm{C}\right]$ leucine and the extent of labelling of plasma L- $\left[1-{ }^{13} \mathrm{C}\right]$ ketoisocaproic acid as this is thought to be a better indicator of intracellular leucine metabolism than plasma leucine. ${ }^{6}$ The rate of leucine oxidation to $\mathrm{CO}_{2}$ was calculated from the total $\mathrm{CO}_{2}$ production rate and the breath ${ }^{13} \mathrm{CO}_{2}$ concentration.

\section{STATISTICAL ANALYSIS}

Results are expressed in terms of the mean and 95\% confidence interval. The paired $t$ test was used to compare disease activity, energy intake, and rates of protein turnover before and after treatment.

\section{Results}

WHOLE BODY PROTEIN TURNOVER

Plateau enrichments of breath ${ }^{13} \mathrm{CO}_{2}$, and plasma L- $\left[1-{ }^{13} \mathrm{C}\right]$ ketoisocaproic acid were achieved during the last 60 minutes. Rates of protein breakdown invariably exceeded rates of 
TABLE I Characteristics of the patients

\begin{tabular}{|c|c|c|c|c|}
\hline $\begin{array}{l}\text { Patient } \\
\text { number }\end{array}$ & $\begin{array}{l}\text { Age } \\
(y r)\end{array}$ & $\begin{array}{l}\text { Duration } \\
(y r)\end{array}$ & Sites & $\begin{array}{l}\text { Treatment } \\
\text { Group }\end{array}$ \\
\hline $\begin{array}{c}1 \\
2 \\
3 \\
4 \\
\text { Mean }\end{array}$ & $\begin{array}{r}13 \cdot 9 \\
17 \cdot 5 \\
15 \cdot 5 \\
8 \cdot 3 \\
13 \cdot 8\end{array}$ & $\begin{array}{l}2 \cdot 1 \\
2 \cdot 0 \\
0 \cdot 4 \\
0 \cdot 2 \\
1 \cdot 2\end{array}$ & $\begin{array}{l}\text { Colon } \\
\text { Ileum + colon } \\
\text { Ileum + colon } \\
\text { Colon }\end{array}$ & Steroids \\
\hline $\begin{array}{l}5 \\
6 \\
7 \\
8 \\
9 \\
10 \\
\text { Mean }\end{array}$ & $\begin{array}{r}17 \cdot 0 \\
11 \cdot 5 \\
11 \cdot 9 \\
12 \cdot 9 \\
14 \cdot 4 \\
8 \cdot 2 \\
13 \cdot 1\end{array}$ & $\begin{array}{l}3 \cdot 2 \\
1 \cdot 0 \\
2 \cdot 4 \\
0 \cdot 6 \\
1 \cdot 1 \\
0 \cdot 1 \\
1 \cdot 4\end{array}$ & $\begin{array}{l}\text { Ileum +colon } \\
\text { Ileum } \\
\text { Ileum } \\
\text { Colon } \\
\text { Ileum } \\
\text { Colon }\end{array}$ & $\begin{array}{l}\text { Elemental } \\
\text { diet }\end{array}$ \\
\hline
\end{tabular}

synthesis, as expected for studies carried out in the postabsorptive state. Mean rates of whole body protein synthesis and breakdown decreased markedly in both treatment groups (Table II) but there were no significant changes in protein balance (synthesis-breakdown) before and after treatment.

\section{ENERGY INTAKE}

The mean energy intake increased from $85 \%$ to $130 \%$ of the recommended daily allowance in the steroid treated group and from $87 \%$ to $112 \%$ in the elemental diet treated group (Table III).

\section{DISEASE ACTIVITY}

The mean increase in the Lloyd-Still activity index was 13 (74 to 87) in the group treated with the elemental diet, not significantly different from the mean increase of 14 (70 to 84) in the group treated with steroids. In the patients with predominantly colonic disease (two treated with steroids and two treated with elemental diet) the mean increase in activity index was 9.5 in each of the two treatment groups (Table III).

\section{Discussion}

These results confirm an earlier study that elemental diets are as effective as steroids in the treatment of acute childhood Crohn's disease. Some authors have described a poorer therapeutic response in patients with predominantly colonic involvement ${ }^{8}$ but others have found that elemental diets may be effective in such patients. ${ }^{910}$ In the present study, the elemental diet was as effective as steroids in the treatment of predominantly colonic disease but there were only two patients in each treatment group. A recent randomised study has suggested that the time to relapse may be shorter in children treated

TABLE II Whole body protein turnover in childhood Crohn's disease (mean and 95\% confidence interval)

\begin{tabular}{llcc}
\hline & All patients & Elemental diet & Steroids \\
\hline $\mathrm{n}$ & 10 & 6 & 4 \\
Protein pretreatment & $152(131$ to 172$)$ & $152(123$ to 181$)$ & 151 (95 to 206) \\
Synthesis post treatment & $121(107$ to 135$)$ & $124(104$ to 143$)$ & $117(79$ to 155$)$ \\
p & 0.001 & 0.031 & 0.036 \\
Protein pretreatment & $170(146$ to 194$)$ & $167(133$ to 201$)$ & $174(112$ to 236$)$ \\
Breakdown post treatment & $138(121$ to 154$)$ & $136(116$ to 156$)$ & $140(91$ to 189$)$ \\
p & 0.002 & 0.041 & 0.043 \\
Protein pretreatment & $-18 \cdot 3(-12 \cdot 0$ to $-24 \cdot 6)-14.8(-7 \cdot 4$ to $-22 \cdot 3)$ & $-23 \cdot 5(-8 \cdot 8$ to $-38 \cdot 2)$ \\
Balance post treatment & $-16.4(-9 \cdot 1$ to $-23 \cdot 7)$ & $-12 \cdot 2(-6 \cdot 2$ to $-18 \cdot 2)$ & $-22 \cdot 8(-2 \cdot 0$ to $-43 \cdot 5)$ \\
p & 0.551 & 0.369 & 0.923 \\
\hline
\end{tabular}

TABLE III Energy intake and disease activity pre and post treatment

\begin{tabular}{|c|c|c|c|c|c|}
\hline \multirow{2}{*}{$\begin{array}{l}\text { Patient } \\
\text { number }\end{array}$} & \multicolumn{2}{|c|}{ Activity index } & \multicolumn{2}{|c|}{$\begin{array}{l}\text { Energy intake } \\
(\% R D A)\end{array}$} & \multirow{2}{*}{$\begin{array}{l}\text { Treatment } \\
\text { group }\end{array}$} \\
\hline & Pre & Post & Pre & Post & \\
\hline $\begin{array}{c}1 \\
2 \\
3 \\
4 \\
\text { Mean }\end{array}$ & $\begin{array}{l}87 \\
64 \\
74 \\
53 \\
70\end{array}$ & $\begin{array}{l}93 \\
85 \\
88 \\
69 \\
84\end{array}$ & $\begin{array}{r}68 \\
72 \\
116 \\
85 \\
85\end{array}$ & $\begin{array}{r}94 \\
94 \\
151 \\
181 \\
130\end{array}$ & Steroids \\
\hline $\begin{array}{l}p_{5} \\
6 \\
7 \\
8 \\
9 \\
10 \\
\text { Mean } \\
\text { p }\end{array}$ & $\begin{array}{l}0.02 \\
67 \\
80 \\
68 \\
84 \\
72 \\
74 \\
74 \\
0.008\end{array}$ & $\begin{array}{l}74 \\
89 \\
93 \\
90 \\
91 \\
87 \\
87\end{array}$ & $\begin{array}{r}30 \\
32 \\
101 \\
88 \\
98 \\
98 \\
102 \\
86 \\
0\end{array}$ & $\begin{array}{r}106 \\
152 \\
91 \\
106 \\
106 \\
112 \\
112\end{array}$ & $\begin{array}{c}\text { Elemental } \\
\text { diet }\end{array}$ \\
\hline $\begin{array}{l}\text { All patients } \\
\text { Mean } \\
\text { p }\end{array}$ & $\begin{array}{l}72 \\
<0.001\end{array}$ & 86 & & 119 & \\
\hline
\end{tabular}

RDA = recommended daily allowance.

with an elemental diet than in those treated with steroids" but a retrospective study in adults showed no significant difference in longterm relapse rates. ${ }^{10}$

The marked decrease in rates of whole body protein turnover in both treatment groups supports the findings of Powell-Tuck et $a l^{2}$ that protein turnover is correlated with disease activity and contrasts with the results of Motil et $a l^{\prime}$ that acute inflammation and steroid therapy had no effect on whole body protein turnover. The reason for the discrepancy is uncertain but may be related to differences in the patient study groups. Motil's patients all had growth failure, a protein intake exceeding the recommended daily allowance and an energy intake appropriate for the height age. They were studied in the fed state and four patients were on steroids at the time of the study. The patients in the present study were initially on no treatment and had normal growth, suggesting milder disease activity. Energy intake was well below the recommended daily allowance initially but increased substantially after starting treatment.

The patients were all in negative protein balance and despite the changes in protein turnover there were no significant differences in overall protein balance before and after treatment. This presumably reflects the fact that the studies were carried out in the postabsorptive state and further studies are required in fed patients. All of the children in this study had normal growth and further studies are also required to examine the relationship between protein turnover, growth failure, and the effects of therapeutic intervention. The elemental diet was well tolerated orally and may be considered as the treatment of choice, thus avoiding the side effects associated with steroid therapy. Dr Thomas was a clinical research fellow with the Crohn's in Childhood Research Association. We are extremely grateful to the North Western Regional Health Authority ar

Motil KJ, Grand RJ, Matthews DE, Bier DM, Maletskos CJ, Motil KJ, Grand RJ, Matthews DE, Bier DM, Maletskos CJ,
Young VR. Whole body leucine metabolism in adolescents Young VR. Whole body leucine metabolism in adolescents with Crohn's disease and growth failure during nutrition
supplementation. Gastroenterology 1982; 82: 1359-68.

2 Powell-Tuck J, Garlick PJ, Lennard-Jones JE, Waterlow JC. Rates of whole body protein synthesis and breakdown increase with the severity of inflammatory bowel disease. Gut 1984; 25: $460-4$. 
3 Lloyd-Still JD, Green OC. A clinical scoring system for chronic inflammatory bowel disease in children. Dig Dis Sci $1979 ; 24: 620-4$.

4 Department of Health and Social Security. Recommended daily amounts of food energy and nutrients for groups of people in the
UK. Report on health and social subjects 15 . London: HMSO, 1969.

5 Matthews DE, Motil KJ, Rohrbaugh DK, Burke JF, Young VR, Bier DM. Measurement of leucine metabolism in man VR, Bier DM. Measurement of leucine metabolism in man
from a primed, continuous infusion of $\mathrm{L}-\left[1-^{13} \mathrm{C}\right]$ leucine.

6 Bennet WM, Connacher AA, Scrimgeour CM, Smith K, Rennie MJ. Increase in anterior tibialis muscle protein synthesis in healthy man during mixed amino acid infusion: studies of incorporation of $\mathrm{L}-\left[1^{-13} \mathrm{C}\right]$ leucine. Clin Sci 1989; 76: 447-54.

7 Sanderson IR, Udeen S, Davies PSW, Savage MO, Walker-
Smith JA. Remission induced by an elemental diet in small bowel Crohn's disease. Arch Dis Child 1987; 61: 123-7.

8 Lochs H, Egger-Schodl M, Schuh R, Meryn S, Westphal G, Potzi $R$. Is tube feeding with elemental diets a primary Potzi R. Is tube feeding with elemental diets a primary
therapy of Crohn's disease? Klin Wochenschr 1984; 62: 821-5.

9 Axelsson C, Jarnum S. Assessment of the therapeutic value of an elemental diet in chronic inflammatory bowel disease. Scand $\mathcal{F}$ Gastroenterol 1977; 12: 89-95.

10 Teahon K, Bjarnason I, Pearson M, Levi AJ. Ten years' experience with an elemental diet in the management of Crohn's disease. Gut 1990; 31: 1133-7.

11 Seidman EG, Lohoues MJ, Turgeon J, Bouthillier L, Morin $\mathrm{CL}$. Elemental diet versus prednisone as initial therapy in Crohn's disease: early and long term results. Gastroenterology 1991; 100: A250. 